\title{
In vitro Antineoplastic Activity of Dye Compounds on Human Glioblastoma Cells
}

\author{
OANA ALEXANDRU ${ }^{1}$, ADA MARIA GEORGESCU ${ }^{1}$, ALEXANDRA DRAGOI ${ }^{1}$, MARIUS EUGEN CIUREA ${ }^{2}$, CITTO IULIAN TAISESCUㄹ, \\ LIGIA GABRIELA TATARANU³, CORINA BRINDUSA ${ }^{1}$, MIHAI VIRGIL BOLDEANU4', STEFANA OANA PURCARU ${ }^{1}$, \\ CRISTIAN ADRIAN SILOSI ${ }^{5}$, ALIN DEMETRIAN 6 , ANICA DRICU1* \\ 'University of Medicine and Pharmacy of Craiova, Department of Functional Science, 2-4 Petru Rares Str., 200349, Craiova, \\ Romania \\ 2 University of Medicine and Pharmacy of Craiova, Department of Plastic and Reconstructive Surgery, 2 Petru Rares Str., 200349, \\ Craiova, Romania \\ ${ }^{3}$ Bagdasar-Arseni Emergency Clinical Hospital, Bucharest, Department of Neurosurgery, 12 Berceni Road, 041915, Bucharest, \\ Romania \\ ${ }^{4}$ University of Medicine and Pharmacy of Craiova, Department of Immunology, 2-4 Petru Rares Str., 200349, Craiova, Romania \\ 5 University of Medicine and Pharmacy of Craiova, Department of Surgery, 2 Petru Rares Str., 200349, Craiova, Romania \\ 6University of Medicine and Pharmacy of Craiova, Department of Thoracic Surgery, 2 Petru Rares Str., 200349, Craiova, Romania
}

Dyes are an important class of natural and synthetic compounds, recently studied as potential anticancer drugs. Among various natural dye molecules, Curcumin was extensively studied in treatment of malignant gliomas, a highly incurable disease. Curcumin was reported to induce cell death in malignant gliomas by induction autophagy and apoptosis. We have previously reported that Helianthin, a synthetic dye compound, also induced apoptotic cell death in high grade glioma cells. In this study we evaluated the antiproliferative and the apoptotic effect of Curcumin and Helianthin on a human low passage glioblastoma cell line. We found that both compounds displayed antiproliferative properties on glioblastoma cells, however, at equimolar concentrations, Helianthin induced more cytotoxic effect than Curcumin. IC50 value is considered a good indicator of drug efficacy. We found that Helianthin required a lower concentration to achieve IC50 (16.9.735 $\pm 14.8 \mu \mathrm{M})$ than Curcumin $(68.5 \pm 12.3 \mu \mathrm{M})$. We also found that Curcumin and Helianthin treatment induced caspase 3, 8 and 9 activation in glioblastoma cells. This study may lead to a widespread search for dye agents that may represent an untapped source of drugs for cancer treatment.

Keywords: dye compounds, Curcumin, Helianthin, apoptosis, glioblastoma, therapy

Dyes compounds, are either natural (e.g. Curcumin, Quercetin) or synthetic (e.g. Helianthin, Methyl Yellow, Methyl Red) products that representa new promising class of anti-tumor drugs. In the last years, these substances gained attention as chemotherapeutic agents because of their cytotoxic efect on malignat cells as well as their favorable toxicity profile in vivo.

Dye compounds have been demonstrated to have antiproliferative effects on cancer cells, by interfering with receptor tyrosine kinases (RTKs) signaling, some of them inducing apoptosis in malignant cells [1-3].

Natural products are considered a very important source of antineoplastic agent, a vast numbers of drugs used in cancer treatment are plant-derived natural products $[4,5]$. The most common natural dye compound, Curcumin, shows promise as potential new antineoplastic drug in vivo and in vitro, in several types of malignancies. However, the substance has not yet reached the levels of drugs that may be suitable for use in clinical practice. Curcumin, also known as Turmeric, is used from ancient times in Indian medicine. The substance is a natural phenolic compound extracted from the plant Curcuma longa and was used from antiquity for treatment of several diseases [6] and proved to have antiproliferative, antimetastatic, antiangiogenic and antimutagenic capacities on various types of solid tumors [7-9]. Turmeric has a growth inhibitory effect on many types of malignant cells including liver, pancreas, breast, colon,kidney, prostate, skin, blood, [10, 11] and also inhibits the proliferation of glioblastoma [12].
The efficacy of Curcumin in glioblastoma treatment was investigated by many research groups. It's antiproliferative effects on glioblastoma cells first demonstrated in vitro by Ambegaokar et al. in 2003 [12]. Nextyears, other scientists demonstrated the efficacy of Curcumin used either alone or in combination to other chemotherapeutics or radiation therapy [13]. Turmeric is able to initiate apoptosis in glioblastoma cells through the activation of poly ADP ribose polymerase (PARP) and caspases activation [14]. Also, in glioblastoma cells, Curcumin acts as inhibitor of growth protein 4 (ING4) signaling pathway, activates a nonapoptotic autophagy signal, induces differentiation cascade, activates proteolytic pathways and induces apoptosis mediated through apo2 ligand and tumor necrosis factor (TNF)-related apoptosis-inducing ligand (TRAIL/Apo2L) [15, 16].

Curcumin was tested in vivo and, in spite the limited number of studies, the results are encouraging. In 2012 Wolff et al. published the preliminary promising data of a clinical trial which used curcumin in association with other treatments for a personalized and targeted therapy in pediatric brain tumors [17].

The antimicrobial properties of synthetic dye compounds (i.e., methylene blue, trypan red, Acridine) were known from the middle $19^{\text {th }}$ century. Now researchers began to ask whether synthetic dye moieties have anticancer properties. Acridine and its derivatives were shown to exhibit antineoplastic effect on cervical and lung cancer cells in vivo [18]. 
Further use of this type of dye substances was investigated as a treatment for other tumor cells with a very promising early result [19].

In our previous work, we also found that Helianthin (methyl orange), a synthetic azo-dye compound, induced cell death in high grade glioma cell lines. We also found that the substance induced apoptosis by PARP degradation, without affecting the expression of B-cell lymphoma 2 (BCl2) [2]. In this paper, we evaluate and compare the antiproliferative and the apoptotic effect of Curcumin and Helianthin on a human low passage glioblastoma cell line. Unlike established cell lines, low-passage cell cultures seem to preserve in a better way the features of the original tumor.

\section{Experiemntal part}

Materials and methods

Cell lines and cell culture. The human primary glioblastoma cell line GB10B, is a low passage primary brain tumor cell line derived from fresh glioblastoma tissue. The tumor was collected from a patient diagnosed with glioblastoma and surgically operated, following standard procedures at Bagdasar-Arseni Hospital in Bucharest. The informed consent of the patient and the ethical approval for the project (Commission for Ethics and Deontology UMF of Craiova) were obtained prior to surgery and any experiment. The tissue was mechanical and enzymatic digested and after the trituration and filtration, the sample was centrifuged for $10 \mathrm{~min}$ and the cells were resuspended and cultured using standard procedures. The cell line was grown in minimum essential medium eagle (MEM) containing $10 \%$ fetal bovine serum (FBS), $2 \mathrm{mM}$ glutamine and antibiotic (100 UI/ $\mathrm{mL}$ penicilline and $100 \mathrm{UI} / \mathrm{mL}$ streptomycine). The cells were incubated at 37 and $5 \%$ $\mathrm{CO}_{2}$ in a humidified incubator ( $\mathrm{CO}_{2}$ Incubator Innova COincubated at 170) in $25 \mathrm{~cm}^{2}$ culture cell bottles.

\section{Curcumin preparation}

Curcumin was purchased from Sigma Aldrich. The Curcumin powder was dissolved in Dimethyl Sulfoxide (DMSO) in order to obtain a $100 \mathrm{mM}$ stock solution. The solution was stored at $-20^{\circ} \mathrm{C}$, protected from light. We used different concentrations $(0.1 \mu \mathrm{M}, 1 \mu \mathrm{M}, 2 \mu \mathrm{M}, 5 \mu \mathrm{M}, 10 \mu \mathrm{M}$, $20 \mu \mathrm{M}, 50 \mu \mathrm{M}, 100 \mu \mathrm{M}, 150 \mu \mathrm{M})$ of Curcumin by diluting the stock solution with standard medium.

\section{Helianthin preparation}

Helianthin (Methyl Orange), was purchased from SantaCruz. The Helianthin powder was dissolved in $\mathrm{H}_{2} \mathrm{O}$ in order to obtain a $100 \mathrm{mM}$ stock solution. The solution was stored at $-20^{\circ} \mathrm{C}$, protected from light. We used different concentrations $(0.1 \mu \mathrm{M}, 1 \mu \mathrm{M}, 2 \mu \mathrm{M}, 5 \mu \mathrm{M}, 10 \mu \mathrm{M}, 20 \mu \mathrm{M}$, $50 \mu \mathrm{M}, 100 \mu \mathrm{M}, 150 \mu \mathrm{M})$ of Helianthin by diluting the stock solution with standard medium.

\section{MTT cellular proliferation assay}

The antiproliferative effect of Curcumin and of Helianthin, was examined using MTT assay (Sigma Aldrich). The assay is based upon the cleavage of the yellow tetrazolium salt MTT (3-(4,5-dimethylthiazol-2-yl)-2,5diphenyl tetrazolium bromide) to purple formazan crystals by metabolically active cells. Tests were conducted with 4000 cells/well, plated in $200 \mu \mathrm{L}$ media in 96-well plates, with six replicates. Cells proliferation was quantified $72 \mathrm{~h}$ after treatment., MTT reagent $(10 \mu \mathrm{L})$ was added to each well and then incubated for $4 \mathrm{~h}$ at $37^{\circ} \mathrm{C}$. After that, cells were lysed by addition of $100 \mu \mathrm{L}$ solubilization buffer. Optical density was measured using a spectrophotometer at 595 $\mathrm{nm}$ and relative cell viability was expressed as percentage of that in untreated control cultures.

IC50 calculation. To estimate the inhibitory concentration that kills $50 \%$ of cells (IC50), the formula used was:

$$
\mathrm{IC} 50=[(50-\mathrm{X}) /(\mathrm{Y}-\mathrm{X})] \times(\mathrm{W}-\mathrm{Z})+\mathrm{Z} .
$$

where $X$ is the first point on the curve, expressed as percent inhibition, that is less than $50 \%, Y$ is the first point on the curve, expressed as percent inhibition, that is greater than or equal to $50 \%$; $Z$ is the concentration of inhibitor that gives $\mathrm{X} \%$ inhibition; and $\mathrm{W}$ refers to the concentration of inhibitor that gives Y\% inhibition. IC50 value was calculted from the dose-response curves for each compound [20, 21].

\section{Cell apoptosis assay}

Apoptosis was analyzed using ApoTarget Caspase-3 (CPP32) Colorimetric Protease Assay kit, ApoTarget Caspase-8 (FLICE) Colorimetric Protease Assay kit, ApoTarget Caspase-9 (Mch6/Apaf-3) Colorimetric Protease Assay kit using the manufacturer's recommendation (Invitrogen, Life Tefnologies, USA). Caspases are cysteine protease, which exist as inactive pro-forms. By inducing apoptosis, they are cleaved to active form. For experimental purposes we seeded into $10 \mathrm{~cm}$ Petri dishes. The cells treated with IC50 concentration of the Curcumin and Helianthin (taken from dose response) for 4, 8, 24, $48 \mathrm{~h}$ or untreated cells were trypsinated and the cytosolic fraction was isolated at a concentration of $3 \times 10^{6}$ per sample. The samples were transferred in 96-well plates, after adding $50 \mu \mathrm{L}$ of $2 \times$ Reaction Buffer/DTT (10 mM dithiothreitol) to each sample and $5 \mu \mathrm{L}$ of $4 \mathrm{mM}$ IEDT-Pna (Ile-Glu-Thr-Asp/ p-nitroanilide) substrate per sample the plates were incubated at $37^{\circ} \mathrm{C}$ in a dark incubator for $2 \mathrm{~h}$. The samples were read at an absorbance of $405 \mathrm{~nm}$ in a 96-well microplate reader at a spectrophotometer Star Fax-2100 (AWARENESS TECHNOLOGY INC).

\section{Statistical analysis}

All data are represented as mean \pm SEM. Data were analysed using ANOVA two-tailed t-test test for analysis. P $<0.05$ values were considered statistically significant.

\section{Results and discussions}

The effect of Curcumin and of Helianthin on glioblstoma cell viability.

In the present work we investigated the ability of Curcumin and of Helianthin to inhibit GB10B cells growth in vitro. The cells were exposed to increasing doses of Curcumin and Helianthin respectively. The concentrations of the two studied dye compounds varied from $0.1 \mu \mathrm{M}$ to $150 \mu \mathrm{M}$. The proliferation rates were evaluated 3 days after treatment by performing the MTT assay (Material and methods section).

Our results showed that Curcumin reduced cell survival by a maximum of $77 \%$ when compared with control cells. The concentration of Turmeric that induced this cytotoxic effect was of $100 \mu \mathrm{M}$. This was statistically significant compared with normal controls $(p<0.05)$ (fig. 1). Minimum inhibitory concentration of Curcumin was $0.1 \mu \mathrm{M}$ and provoked only approximately $2 \%$ GB10B cell death. Higher Curcumin concentrations did not induce more cytotoxicity (fig. 1).

Helianthin treatment also had antiproliferative effect on GB10B cells. While minimum inhibitory concentration ( 0.1 iM) induced only approximately $10 \%$ cells death, $100 \mu \mathrm{M}$ Helianthin reduced cell survival by approximately $85 \%$ 

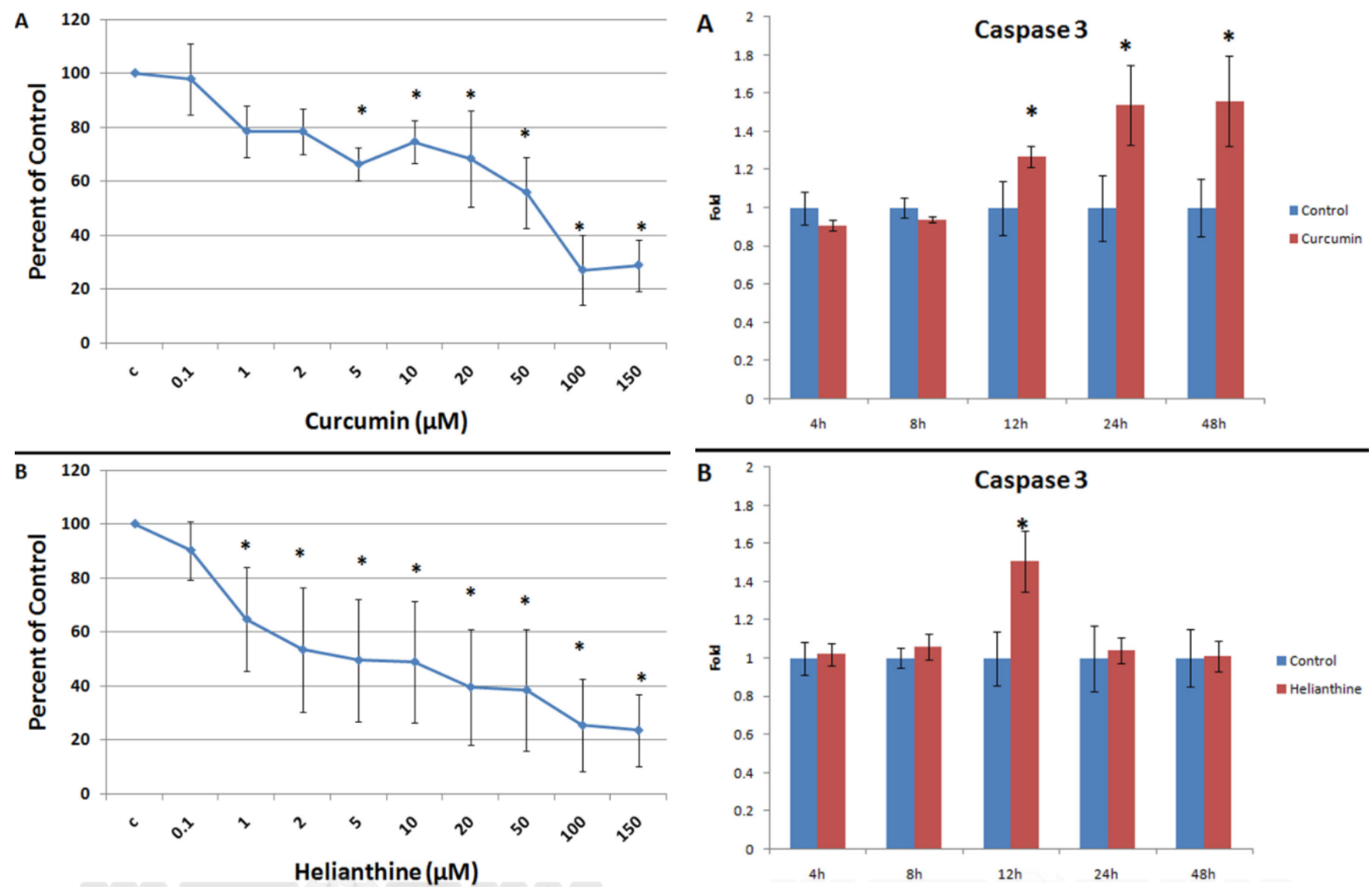

Fig. 1. The effect of Curcumin and Helianthin on GB10B cells. Cells seeded at $5 \times 10^{4}$ cells/well were grown in standard medium. Cytotoxic effects of Curcumin (A) and Helianthin was evaluated following treatment with increasing drugs concentrations $(0.1,1,2$, $5,10,20,50,100$ and $150 \mu \mathrm{M}$ ) at $72 \mathrm{~h}$, by MTT assay. Results are expressed as percentage of control. Data are mean and standard error of at least three separate experiments. Error bars are the mean \pm SD for each drug concentration and represent the linear model fit to the data.

* Represents significant difference from control $(p<0.05)$

when compared with untreated control glioblastoma cells. Similar results were obtained when used 150uM Helianthin when the decrease of cells survival was of approximately $86.5 \%$. This decrease in cell survival was statistically significant compared with untreated control $(p<0.05)$.

\section{IC50 calculation}

The IC50 value is very important in evaluation of the drug cytotoxic potency. The IC50 value is also important when comparing drug effect on different compounds.

We determined the half inhibitory concentration to induce $50 \%$ cell death (IC50) was determined in GB10B cell line for Curcumin and also for Helianthin. We found that IC50 value was $68.5 \pm 12.3 \mu \mathrm{M}$ for Curcumin, and 16.9.735 $\pm 14.8 \mu \mathrm{M}$ for Helianthin. Our result showed that the most potent among two tested dye compounds was Helianthin.

\section{Activation of caspase3, 8 and 9 by Curcumin and Helianthin drugs-induced cell death.}

To evaluate whether the cytotoxicity of Curcumin and Helianthin induced apoptotic cell death, GB10B cells were exposed to IC50 concentration of each drug (taken from dose response) and apoptos induction was determined by caspase 3, 8 and 9 assay.

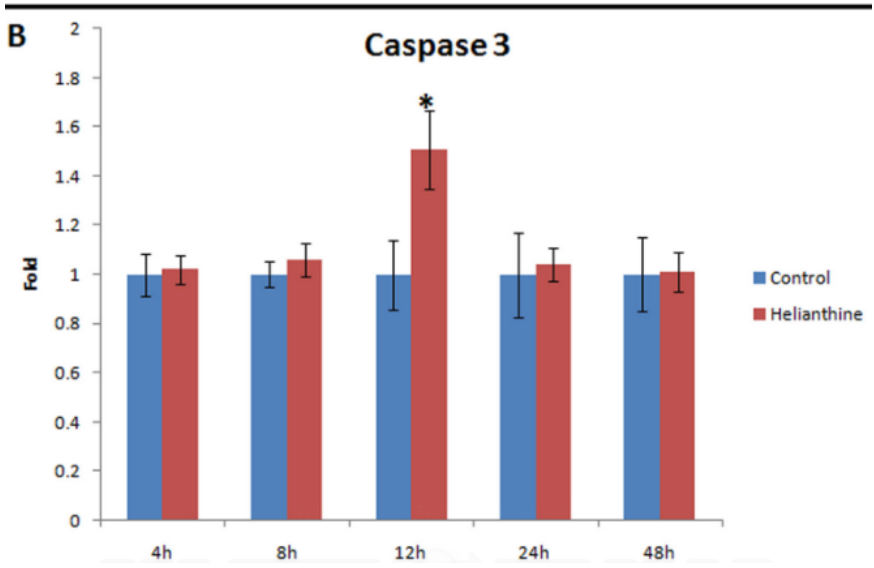

Fig. 2. The levels of caspase 3 induction by treatment with Curcumin and Helianthin in the GB10B cell line. The cells were treated with IC50 concentration of the Curcumin (A) or Helianthin

(B) for 4, 8, 24, $48 \mathrm{~h}$ and activation of caspase 3 was determined according to manufacturer's instructions (Invitrogen, Life Tefnologies, USA). Results are expressed as fold increase relative to control. Data are represented as mean and standard deviation from at least three separate experiments,

$*$ Represents significant difference from control $(p<0.05)$

\section{Caspase 3 activation}

Caspase 3 is an executioner caspase involved in the coupling between the extrinsic and the intrinsic pathways of apoptosis. The activation of caspase 3 is subsequent to the activation of caspase 8 and 9 . Several research studies demonstrated that Curcumin treatment activates caspase 3 in glioblastoma cells [22, 23].

In this part of the study, the cells treated with $68.5 \mu \mathrm{M}$ Curcumin (IC50) or $16.9 \mu \mathrm{M}$ Helianthin (IC50) for 4, 8, 24, $48 \mathrm{~h}$ or untreated cells were assayed. for activation of caspase 3 (fig. 2).

We found that $63.8 \mu \mathrm{M}$ Curcumin induced caspase 3 activation at $12 \mathrm{~h}$ after the treatment and remained active at $24 \mathrm{~h}$ and $48 \mathrm{~h}$ after drug administration (fig. $2 \mathrm{~A}$ ). The treatment with $16.9 \mu \mathrm{M}$ Helianthin induced caspase 3 activation with a peak at 12 ha returned to base-line at 24 and $h$ after the treatment (fig. 2B).

\section{Caspase 8 activation.}

Caspase 8 is an initiator caspase. This proapoptotic protease activation precedes the activation of caspase 3.There are a few number of studies that demonstrated the activation of caspase 8 by Curcumin administration in glioblastoma cells [14, 16, 24].

For caspase 8 evaluation, the cells were treated with IC50 concentration of the Curcumin or Helianthin for 4, 8, $24,48 \mathrm{~h}$ and activation of caspase 8 was determined spectrophotometrically, as indicated in the section Material and Methods. 

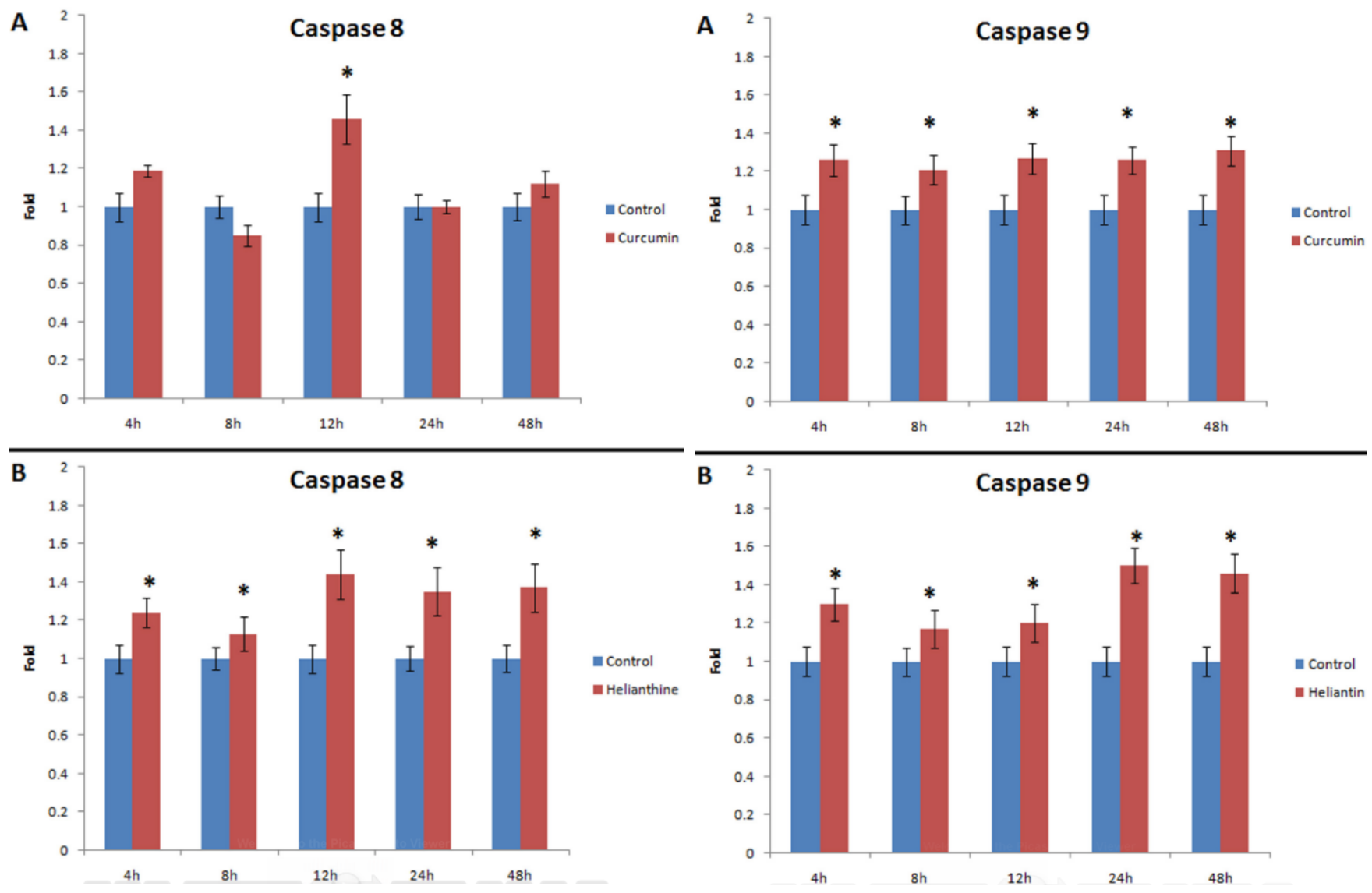

Fig. 3. The levels of caspase 8 induction by treatment with Curcumin and Helianthin in the GB10B cell line. The cells were treated with IC50 concentration of the Curcumin (A) or Helianthin

(B) for 4, 8, 24, $48 \mathrm{~h}$ and activation of caspase 8 was determined according to manufacturer's instructions (Invitrogen, Life Tefnologies, USA). Results are expressed as fold increase relative to control. Data are represented as mean and standard deviation from at least three separate experiments,

* Represents significant difference from control $(p<0.05)$

The treatment with $16.9 \mu \mathrm{M}$ Helianthin induced early caspase 8 activation at $4 \mathrm{~h}$, remained active at $8 \mathrm{~h}$ and progressivelly increased at 12,24 and $48 \mathrm{~h}$ after treatment (fig. 3B). In contrast to Helianthin, 4 and $8 \mathrm{~h}$ incubation with Curcumin at IC50 concentration did not show a significant $(\mathrm{p} \geq 0.05)$ increase of caspase 8 in glioblastoma cell (fig 3A). The treatment induced a significant increase $(p \leq 0.05)$ at $12 \mathrm{~h}$ an returne to base-line at 24 and $48 \mathrm{~h}$ after the treatment (fig. 3A).

\section{Caspase 9 activation}

Caspase 9 activation occurs early in apoptosis preceding both caspase 8 and caspase 3 . In fact, caspase 9 is an initiator caspase involved in the intrinsic pathway of apoptosis. Curcumin treatment proved to induce caspase 9 activation in glioblastoma cells [14, 16, 23] .

In our experiments we evaluated caspase 9 activity by treating the cells with IC50 concentration of the Curcumin or Helianthin for 4, 8, 24 and $48 \mathrm{~h}$ respectively. The activation of caspase 8 was determined spectrophotometrically, as indicated in the section Methods.

Both dye compounds activated caspase 9 at $4 \mathrm{~h}$ after administration. Caspase 9 remained active up to $48 \mathrm{~h}$ after

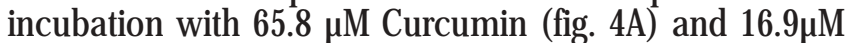
Helianthin (fig. 4B). The results were statistically significant $(p \leq 0.05)$.

Fig. 4. The levels of caspase 9 induction by treatment with Curcumin and Helianthin in the GB10B cell line. The cells were treated with IC50 concentration of the Curcumin (A) or Helianthin

(B) for 4 hours, 8 hours, 24 hours, 48 hours and activation of caspase 9 was determined according to manufacturer's

instructions (Invitrogen, Life Tefnologies, USA). Results are expressed as fold increase relative to control. Data are represented as mean and standard deviation from at least three separate experiments,

* Represents significant difference from control $(p<0.05)$

Glioblastomas, a type IV malignant glioma, are very aggressive brain tumors. In spite of current advances in multimodality therapy the prognosis of these patients remains extremely poor. Recently there are attempts to improve the present therapeutic approaches for these tumors. Among them is the discovery of novel antineoplastic drugs that are more efficient and less aggressive with the healthy tissues [25].

In the lastyears, literature enriched with reports showing that natural products extracted from plants or synthetic structures derived from natural compounds represent a hope for cancer patients. Nowadays, there are publications that underline the reasoning for using those new drugs as anti-tumor therapy alone or in combination with other treatments $[5,26,27]$. Among those new drugs are dyes, a major class of natural and synthetic compounds with a variety of therapeutic properties [27]. In recent years, some azo dye products have shown promise both as a potential antitumour agents alone or in combination with conventional treatment for several types of malignancies.These natural(e.g curcumin, quercetin, saffron etc), or synthetic(e.g. helianthin etc) compounds proved to have antiproliferative efect on neoplastic cells and low toxicity in vivo. They have been demonstrated to have antiproliferative effects on cancer cells, by inhibiting RTKs signaling and inducing apoptosis $[2,12]$. 
In our study we analyzed the antiproliferative and apoptotic effect of Curcumin and Helianthin treatment on GB10B low passage glioblastoma cell line in vitro. In fact, clinical protocols are preceded by preclinical studies of cytotoxicity using immortalized cell lines. However, established cell lines are often unable to reproduce the original tumor characteristics. Also, long-time culture cancer cells tends to accumulate a series of DNA mutations, cells morphology changes, growth rates alterations and expression of dysfunctional proteins [28, 29]. Here, we used a low-passage glioblastoma cell line obtained in our laboratory from fresh tumor tissue.

Several reports sustain the cytotoxic effect of Curcumin on various types of solid tumors, including glioblastomas. The first study that demonstrated the capacity of Curcumin to kill glioblastoma cells was published in 2003 [12]. Since then, various studies were made on different glioblastoma cell lines [22]. Although administration of Turmeric showed encouraging results in vitro, until now the drug was used only in a few clinical trials including one clinical trial of pediatric brain tumors. The preliminary results of this trial are promising but the substance is not yet used as a standard treatment for humans [17]. Our experiments demonstrated that the administration of Curcumin to GB10B culture induced cytotoxicity in a dose dependent manner (fig. 1). The maximum antiproliferative effect of the drug was obtained at $100 \mathrm{i} M$ and determined a reduction in cell viability up to $77 \%$. This Curcumin concentration of $100 \mu \mathrm{M}$ seems to be safe as Turmeric is used in Indian diet for thousands of years and proved no toxicity when administered at doses up to $10 \mathrm{~g} / \mathrm{day}$.

Compared with Curcumin, synthetic azo-dye compound Helianthin was until now studied only on high grade glioma cell lines in vitro. In fact, we have previously shown that the substance induced apoptosis in several high grade glioma cell cultures. Now we found that 100 ì Helianthin drastically induced decrease in cell viability, killing $85 \%$ of GB10B cells. This concentration of Helianthin seems to be safe as it was proved most azo-dyes have a median lethal dose(LD50) values between 250 and $2000 \mathrm{mg} / \mathrm{kg}$ body weight in the mammal tests [30]. Thus, our data showed that synthetic dye Helianthin had a greater cytotoxic effect on GB10B cells when compared with natural dye compound Curcumin. Consistently with our previous work, we observed that 1ìm Helianthin killed approximately $40 \%$ of our GB10B cells [2].

It is already known that programmed cell death (apoptosis) is a vital process in all living cells. However, in glioblastoma cells apoptosis is widely deregulated [31]. In glioblastoma, the intrinsic apoptosis pathway is regulated by the pro-apoptotic protein $\mathrm{BCl} 2$, reported to determine the increase of membrane permeability, which subsequently determines the release of cytochrome 3 . It also induces caspase 9 activation and subsequent activation of caspase 3 [31]. The extrinsic pathway in glioblastoma involves the induction of the death receptors trimerisation, results in the recruitment and activation of caspase 8 and 10. Activation of these caspases leads in the cleavage of target substrates by caspase 3 . In that way the 2 pathways are linked [32, 33].

In our w ork we investigated the capability of Curcumin and of Helianthin to induce apoptosis in GB10B cells. It is already known that Curcumin is capable to induce apoptosis in glioblastoma by activation of pro-apoptotic proteins and inhibition of anti-apoptotic signals. The drug is also involved in the activation of non-apoptotic autophagy, induces differentiation cascade signaling, inhibits matrix metalloproteinases (MMPs) and glucose-6- phosphate transporter (G6PT) gene expression and also activates proteolytic pathways [34, 35]. Here, we observed that after treating GB10B cells with Curcumin, caspase 3 activated at $12 \mathrm{~h}$ after the treatment and remained active up to $48 \mathrm{~h}$ after the administration of the drug. Caspase 8 was active only at $4 \mathrm{~h}$ and $12 \mathrm{~h}$ after Turmeric administration while caspase 9 activated at $4 \mathrm{~h}$ after the administration of the drug. Caspase 9 remained activated up to $48 \mathrm{~h}$ after Curcumin administration.

In our previous studies we reported that Helianthin treatment was associated with PARP degradation without affecting expression of $\mathrm{BCl}-2$ in high grade glioma cell lines [2]. In the present study, we observed that Helianthin activated caspase 3 in GB10B cells only at $12 \mathrm{~h}$ after the administration of the drug (fig. 2B). Caspase 8 was first activated at $4 \mathrm{~h}$ after administering the drug and remained active up to $48 \mathrm{~h}$ after. In contrast to caspase 3 and 8 , after Helianthin treatment, early caspase 9 activation was detected ( 4 hours after the treatment), that successively increased until the end of treatment. These results suggest that Curcumin and Helianthin treatment may induce death in GB10B cells by activation of both extrinsic and intrinsic pathways. However further studies are necessary to better understand the apoptotic mechanisms induced by dye compounds in glioblastoma.

\section{Conclusions}

In conclusion, this study demonstrates that Curcumin and Helianthin treatmentinduces cell death in glioblastoma cells in vitro and Helianthin displayed better antiproliferative capacity than Curcumin. We also found that Curcumin and Helianthin treatment determined caspase 3, 8 and 9 activation in GB10B cells. Further on more studies are necessary to conclude whether Curcumin and Helianthin might be effective chemotherapeutics agents in vivo. More importantly, this study may lead to a widespread search for dye agents that may represent an untapped source of drugs for cancer treatment.

\section{List of abbreviations}

RTK-receptor tyrosine-kinase; PARP-poly ADP ribose polymerase; ING4-inhibitor of growth protein 4; TNF-tumor necrosis factor; Bcl-2-B-cell lymphoma 2; MEM-minimum essential medium eagle; FBS-fetal bovine serum; CPP32ApoTarget Caspase-3;FLICE-Apo Target Caspase-8; MTT(3-(4,5-dimethylthiazol-2-yl)-2,5-diphenyl tetrazolium bromide); DMSO-Dimethyl Sulfoxide; MMP-matrix metalloproteinases;G6PT-glucose-6-phosphate transporter

Acknowledgements: This paper was published under the frame of European Social Found, Human Resources Development Operational Programme 2007-2013, Project no. POSDRU/ 159/1.5/S/136893 and Executive Agency for Higher Education, Research, Development and Innovation Funding Romania, GrantPN-II-ID-PCE-2011-3-1041, Romania

\section{References}

1.MEHTA, K., PANTAZIS, P., MCQUEEN, T., AGGARWAL, B.B., Antiproliferative effect of curcumin (diferuloylmethane) against human breast tumor cell lines, Anticancer Drugs, 8, 1997, p. 470-481.

2.ALEXANDRU, O., DRAGUTESCU, L., TATARANU, L., ET AL., Helianthin induces antiproliferative effect on human glioblastoma cells in vitro, J. Neurooncol., 102, 2011, p. 9-18.

3.MUKHOPADHYAY, A., BUESO-RAMOS, C., CHATTERJEE, D., ET AL., Curcumin downregulates cell survival mechanisms in human prostate cancer cell lines, Oncogene, 20, 2001, p. 7597-7609.

4.NOBILI, S., LIPPI, D., WITORT, E., ET AL., Natural compounds for cancer treatment and prevention, Pharmacol. Res., 59, 2009, p. 365378. 
5.AMIN, A., GALI-MUHTASIB, H., OCKER, M., SCHNEIDER-STOCK, R., Overview of major classes of plant-derived anticancer drugs, Int. J. Biomed. Sci., 5, 2009, p. 1-11.

6.AMMON, H.P., WAHL, M.A., Pharmacology of Curcuma longa, Planta Med., 57, 1991, p. 1-7.

7.GUPTA, S.C., PATCHVA, S., AGGARWAL, B.B., Therapeutic roles of curcumin: lessons learned from clinical trials, AAPS J., 15, 2013, p. 195-218.

8.ALINEJAD, B., GHORBANI, A., SADEGHNIA, H.R., Effects of combinations of curcumin, linalool, rutin, safranal, and thymoquinone on glucose/serum deprivation-induced cell death, Avicenna J. Phytomed., 3, 2013, p. 321-328.

9.NOORAFSHAN, A., ASHKANI-ESFAHANI, S., A review of therapeutic effects of curcumin, Curr. Pharm. Des., 19, 2013, p. 2032-2046.

10.BAYET-ROBERT, M., KWIATKOWSKI, F., LEHEURTEUR, M., ET AL., Phase I dose escalation trial of docetaxel plus curcumin in patients with advanced and metastatic breast cancer, Cancer Biol. Ther., 9, 2010, p. 8-14

11.IDE, H., TOKIWA, S., SAKAMAKI, K., ET AL., Combined inhibitory effects of soy isoflavones and curcumin on the production of prostatespecific antigen, Prostate, 70, 2010, p. 1127-1133.

12.AMBEGAOKAR, S.S., WU, L., ALAMSHAHI, K., ET AL., Curcumin inhibits dose-dependently and time-dependently neuroglial cell proliferation and growth, Neuro. Endocrinol. Lett., 24, 2003, p. 469473.

13.DHANDAPANI, K.M., MAHESH, V.B., BRANN, D.W., Curcumin suppresses growth and chemoresistance of human glioblastoma cells via AP-1 and NFkappaB transcription factors, J. Neurochem., 102, 2007, p. 522-538.

14.KARMAKAR, S., BANIK, N.L., RAY, S.K., Curcumin suppressed antiapoptotic signals and activated cysteine proteases for apoptosis in human malignant glioblastoma U87MG cells, Neurochem. Res., 32, 2007, p. 2103-2113.

15.LIU, E., WU, J ., CAO, W., ET AL., Curcumin induces G2/M cell cycle arrest in a p53-dependent manner and upregulates ING4 expression in human glioma, J. Neurooncol., 85, 2007, p. 263-270.

16.KARMAKAR, S., BANIK, N.L., PATEL, S.J., RAY, S.K., Curcumin activated both receptor-mediated and mitochondria-mediated proteolytic pathways for apoptosis in human glioblastoma T98G cells, Neurosci. Lett., 407, 2006, p. 53-58.

17.WOLFF, J.E., BROWN, R.E., BURYANEK, J., ET AL., Preliminary experience with personalized and targeted therapy for pediatric brain tumors, Pediatr. Blood Cancer, 59, 2012, p. 27-33.

18.KUMAR, P., KUMAR, R., PRASAD, D.N., Synthesis and anticancer study of 9-aminoacridine derivatives, Arabian J. Chem., 6, 2013, p. 7985.

19.KAWAKAMI, M., KOYA, K., UKAI, T., ET AL., Structure-activity of novel rhodacyanine dyes as antitumor agents, J. Med. Chem., 41, 1998, p. 130-142.
20.MAHATA, S., MARU, S., SHUKLA, S., ET AL., Anticancer property of Bryophyllum pinnata (Lam.) Oken. leaf on human cervical cancer cells. BMC Complement Altern. Med., 12, 2012, p. 15.

21.YAN, Z., CALDWELL, G.W., Evaluation of cytochrome P450 inhibition in human liver microsomes. In Optimization in Drug Discovery, Springer, 2004, p. 231-244.

22.ZANOTTO-FILHO, A., BRAGANHOL, E., EDELWEISS, M.I., ET AL., The curry spice curcumin selectively inhibits cancer cells growth in vitro and in preclinical model of glioblastoma, J. Nutr. Biochem., 23, 2012, p. 591-601.

23.HUANG, T.Y., TSAI, T.H., HSU, C.W., HSU, Y.C., Curcuminoids suppress the growth and induce apoptosis through caspase-3dependent pathways in glioblastoma multiforme (GBM) 8401 cells, J. Agric. Food Chem., 58, 2010, p. 10639-10645.

24.HOSSAIN, M., BANIK, N.L., RAY, S.K., Synergistic anti-cancer mechanisms of curcumin and paclitaxel for growth inhibition of human brain tumor stem cells and LN18 and U138MG cells, Neurochem. Int., 61, 2012, p. 1102-1113.

25.MAO, H., LEBRUN, D.G., YANG, J., ET AL., Deregulated signaling pathways in glioblastoma multiforme: molecular mechanisms and therapeutic targets, Cancer Invest., 30, 2012, p. 48-56.

26.RAJESH, E,, SANKARI, L.S., MALATHI, L., KRUPAA, J.R., Naturally occurring products in cancer therapy, J. Pharm. Bioallied. Sci., 7, 2015, p.S181-183.

27.AGGARWAL, B.B., SUNDARAM, C., MALANI, N., ICHIKAWA, H., Curcumin: the Indian solid gold, Adv. Exp. Med. Biol., 595, 2007, p. 175.

28.SAMBUY, Y., DE ANGELIS, I., RANALDI, G., ET AL., The Caco-2 cell line as a model of the intestinal barrier: influence of cell and culturerelated factors on Caco-2 cell functional characteristics, Cell Biol. Toxicol., 21, 2005, 1-26.

29.CHANG-LIU, C.M., WOLOSCHAK, G.E., Effect of passage number on cellular response to DNA-damaging agents: cell survival and gene expression, Cancer Lett., 113, 1997, p. 77-86.

30.ZEE, F., Anaerobic azo dye reduction, Ph. D. thesis, Wageningen University, Wageningen-Netherlands, 2002.

31.BRENNER, D., MAK, T.W., Mitochondrial cell death effectors, Curr. Opin. Cell Biol., 21, 2009, p. 871-877.

32.AGGARWAL, B.B., Signalling pathways of the TNF superfamily: a double-edged sword, Nat. Rev. Immunol., 3, 2003, p. 745-756.

33.GUICCIARDI, M.E., GORES, G.J., Life and death by death receptors, FASEB J., 23, 2009, p. 1625-1637.

34.NAGAI, S., KURIMOTO, M., WASHIYAMA, K., ET AL., Inhibition of cellular proliferation and induction of apoptosis by curcumin in human malignant astrocytoma cell lines, J. Neurooncol., 74, 2005, p. 105-111. 35.ROMERO-HERNANDEZ, M.A., EGUIA-AGUILAR, P., PEREZPENADIAZCONTI, M., ET AL., Toxic effects induced by curcumin in human astrocytoma cell lines, Toxicol. Mech. Methods, 23, 2013, p. 650-659.

$\overline{\text { Manuscript received: } 15.08 .2018}$ 